\title{
Reasonable Restrictions on Freedom of High Seas by "Marine Protected Areas on the High Seas": An Empirical Research
}

\author{
Yong Wang*
}

The UN member states have been consulting on the establishment of high seas MPAs under the BBNJ Agreement since December 2017.This issue brings about the potential conflicts between the jurisdiction of the high seas MPAs and the traditional freedom of the high seas. Although it is generally accepted that the freedom of the high seas can be reasonably restricted, it is acknowledged that there are great controversies among States on the specific forms, approaches and applicable scopes of the restrictions of the high seas freedoms by the high seas MPAs. At present, there are four recognized high seas MPAs in the world. The practice of these four MPAs contributes positively to the interpretation of the reasonable restrictions on the freedom of the high seas. Accordingly, this paper concludes that the international community should gradually carry forward future restrictions on the freedom of the high seas with some suggestions.

\section{Keywords}

High Seas Marine Protected Areas, Freedom of the High Seas, Reasonable Restrictions, Positivist Analysis

* Professor of International Law at East China University of Political Science and Law ("ECUPL”), China. LL.B./LL.M. /Ph.D. (ECUPL). ORCID: http://orcid.org/0000-0002-4558-3663. This paper is a phased research result of a major project of China Association of Marine Affairs and Academy of Ocean of China entitled, "Research into the Marine Exploitation and Utilization System under the Law of the Sea (CAMAZDA201701)." Much gratitude is extended to Prof. Eric Y. J. Lee for his insightful advice. The author may be contacted at: yongyongsh@163.com/Address: International Law School, East China University of Political Science and Law, No. 1575 Wan hangdu Road, Shanghai, China, 200042. All the websites cited in this paper were last visited on September 23, 2019. 


\section{Introduction}

In the last four decades, marine vertebrates (fish, seabirds, sea turtles, and marine mammals) have significantly declined by 22 percent on average. ${ }^{1}$ A recent review article in Science predicts a major extinction event in the oceans if human impacts on the marine environment go unchecked. ${ }^{2}$ Meanwhile, the protection of marine environment on the high seas has also attracted great attention from the international community. However, the legal and institutional frameworks that govern marine biodiversity in areas beyond national jurisdiction ("ABNJ") are widely perceived as inadequate for ensuring the long-term health and equitable use of the living resources in this vast area. ${ }^{3}$ In order to protect marine environment in ABNJ, representatives from over one hundred States, governments and NGOs participated in the negotiations of drafting a BBNJ convention, which have already completed four precommittee meetings. ${ }^{4}$ After serveral rounds of extensive negotiations, on July 21, 2017, the pre-committee finally submitted the substantive recommendations on the elements of a draft text of an international legally binding instrument ("ILBI") under the 1982 United Nations Convention on the Law of the Sea ("UNCLOS") to the UN General Assembly. ${ }^{5}$ On December 24, 2017, the United Nations General Assembly adopted Resolution 72/249 that decided to initiate formal governmental negotiations on the issue, aiming at drafting a legally binding international document of biological diversities beyond national jurisdiction (“BBNJ"). ${ }^{6}$

One key issue about the BBNJ is the potential establishment of high seas Marine Protected Areas ("MPAs"). ${ }^{7}$ Arguably, the establishment of the high seas MPAs may give rise to potential conflicts between the jurisdiction of high seas MPAs and the

D. McCauley et al., Marine defaunation: animal loss in the global ocean, 347 Scr. 247(2015).

$2 \quad I d$.

3 A.-M. Hubert, UN General Assembly Resolution to Develop a New Legally Binding Instrument on the Conservation and Sustainable Use of Marine Biological Diversity of Areas Beyond National Jurisdiction (Aug. 14, 2015), available at https://ablawg.ca/2015/08/14/un-general-assembly-resolution-to-develop-a-new-legally-binding-instrument-on-theconservation-and-sustainable-use-of-marine-biological-diversity-of-areas-beyond-national-jurisdiction.

4 BBNJ's four pre committees were held in New York as follows: (1) Mar. 28 - Apr. 8, 2016; (2) Aug. 26 - Sept. 9, 2016; (3) Mar. 27 - Apr. 7, 2017; (4) July 10-17, 2017.

5 Id.

6 G.A. Res.72/249, U.N. Doc. A/RES/72/249 (Jan. 19, 2018), available at https://undocs.org/en/A/AC.287/2017/PC.4/2.

7 Id. As the areas beyond national jurisdiction include the high seas and the Area, the MPAs beyond national jurisdiction also include high seas MPAs and the Area MPAs. The paper only borrows the name of high seas MPAs, so the high seas MPAs in this paper not only refer to marine protected areas located on the high seas, but also the international seabed area. 
freedom of the high seas. On the one hand, the principle of the high seas freedom remains to be the foundation of contemporary international law of the sea. ${ }^{8}$ On the other hand, to establish high seas MPAs may bring about certain impact on the management of fishing, navigation, scientific research on the high seas. During the process of the four pre-committee meetings, there were fierce debate among negotiating States over the relationship between the jurisdiction of high seas MPAs and the traditional freedom of the high seas, the management methods of the high seas, the selection criteria for designing the MPAs and the legal effect of management measures on non-contracting States, etc. ${ }^{9}$ At the current stage, a prudential conclusion is that the traditional high seas freedoms shall prevail. Instead, it may merely impose reasonable restrictions on the high seas freedoms.

Against this background, certain questions would be worth considering: What are the appropriate approach, scope and degree of the restrictions set upon the high seas freedom? This paper will take the crucial principles of international law as basis, and provide a comparative analysis of the practice of the four high seas MPAs. ${ }^{10}$ The paper will consider factors such as the international politics and States' practices, and discuss in depth how to properly restrict the high seas freedom on the high seas MPAs, including overall strategies, specific ways and methods of the ristrictions, with the hope to facilitate future BBNJ negotiation process.

\section{An Overview of the Principle of the High Seas Freedom and Its Reasonable Restrictions}

In the early 17th century, Hugo Grotius, often dubbed as "father of modern international law," advocated the principle that the ocean was international territory and all nations were free to use it for seafaring trade. ${ }^{11}$ Since then, Grotius's doctrine has been gradually accepted by the international community and finally became the principle of the freedom of the high seas.

8 M. Nordquist et al., United Nations Convention on the Law of the Sea 1982: A Commentary (vol. 3$) 73$ (1995).

9 See Resource from four pre-committee reports, available at: (1) http://enb.iisd.org/download/pdf/enb25106e.pdf; (2) http://enb.iisd.org/download/pdf/enb25118e.pdf; (3) http://enb.iisd.org/download/pdf/enb25129e.pdf; (4) http://enb. iisd.org/download/pdf/enb25141e.pdf.

10 Namely, Mediterranean Pelagos Sanctuary, Antarctic South Orkney Islands Southern Shelf Marine Protected Area (Antarctic South Orkney Marine Protected Area), North-East Atlantic Marine Reserve and Antarctic Ross Sea Region Marine Protected Area.

11 H. Grotius, The Freedom of the Seas 7-10 (R. van Deman Magoffin trans., 1916). 
Throughout the history, the "freedom of the high seas" is a developing concept, the contents of which have evolved from two freedoms eventually to six freedoms. Initially, the high seas freedoms comprised the freedom of navigation and the freedom of fishing only. ${ }^{12}$ With the emergence of the aircraft, the freedom of overflight became the third freedom. ${ }^{13}$ Then, the 1958 Convention on the High Seas added the freedom to lay submarine cables and pipelines as the fourth freedom. ${ }^{14}$ Finally, the UNCLOS stipulated two additional freedoms of the high seas on the basis of the 1958 Convention on the High Seas, namely the freedom to construct artificial islands and other installations permitted under international law and the freedom of marine scientific research. ${ }^{15}$ It can be concluded that the specific contents of the high seas freedoms are constantly enriched and developed with the enhancement of human capacity to exploit the oceans.

On the other hand, the principle of the high seas freedoms can be reasonably restricted. The reasonable restrictions on the principle of the high seas freedoms are mainly regulated by multilateral treaties. First, the second paragraph of Article 2 of the 1958 Convention on the High Seas imposed a general restriction on the principle of the high seas freedoms. ${ }^{16}$ Second, there are both general and special restrictions on the principle of the high seas freedoms under the UNCLOS. The general restrictions on the principle of the high seas freedoms are manifested in three aspects: First, these freedoms shall be exercised by all States with due regard for the interests of other States in their exercise of the freedom of the high seas. Second, these freedoms shall be exercised with due regard for the rights under the UNCLOS with respect to activities in the Area. ${ }^{17}$ Third, the high seas shall be reserved for peaceful purposes. ${ }^{18}$

However, the aforementioned three restrictions are quite vague. As such, it is difficult to enforce in practice. Meanwhile, with the development of science and technology, human activities in far-off ocean also have significant impacts on coastal states since the middle of the 20th century. ${ }^{19}$ Hence, the modern international law of

13 Convention on International Civil Aviation (Chicago Convention) (Dec. 7, 1944), available at http://kenyalaw.org/ treaties/treaties/63/Convention-on-International-Civil-Aviation-Chicag.

14 High Seas Convention 1958, art. 2.

15 UNCLOS art. 87.1(d).

16 High Seas Convention 1958, art. 2, ๆ 2. It states: "These freedoms, and others which are recognized by the general principles of international law, shall be exercised by all States with reasonable regard to the interests of other States in their exercise of the freedom of the high seas."

17 UNCLOS art. 87.2.

8 Id. art. 88 ,

19 Supra note 2. 
the sea has further restricted the principle of the high seas freedom in recent years under the impetus of the coastal states. For instance, in the field of prevention of marine pollution, a series of multilateral treaties were adopted, such as the 1969 International Convention Relating to Intervention in the High Seas in Cases of Oil Pollution Casualties, the 1973 International Convention for the Prevention of Pollution from Ships ("MARPOL") and its 1978 Protocol. In the field of resource conservation, there are the 1993 Agreement to promote compliance with international conservation and management measures by fishing vessels on the high seas, the Agreement for the Implementation of the Provisions of the United Nations Convention on the Law of the Sea of 10 December 1982 relating to the Conservation and Management of Straddling Fish Stocks and Highly Migratory Fish Stocks (hereinafter Straddling Fish Stocks Agreement ) and the 1999 Code of Conduct for Responsible Fisheries, etc. According to the International Convention Relating to Intervention in the High Seas in Cases of Oil Pollution Casualties, parties may take necessary measures on the high seas to prevent, mitigate or eliminate grave and imminent danger to their coastline or related interests from pollution or threat of pollution of the sea by oil. The MARPOL and its 1978 Protocol also cover all waste discharged by ships, and extend the scope of application of ships to any vessel navigating at sea. With regard to the resources conservation, the 1995 Straddling Fish Stocks Agreement extended the scope of jurisdiction that regional fisheries management organizations have on exclusive economic zones and the high seas to non-organizational parties and non-contracting parties. More importantly, according to the agreement, flag states may be authorized to board and inspect the vessels of non-flag states on the high seas under certain circumstances. $^{20}$

In addition to multilateral treaties, the principle of the high seas freedom can also be restricted by customary international law. According to customary international law, a warship or a military aircraft has the right to combat piracy, as well as to board and inspect Stateless ships. ${ }^{21}$

To sum up, the principle of the high seas freedoms is by no means absolute. Although the principle of the high seas freedom is still the foundation of contemporary international law of the sea, it is increasingly restricted by multilateral treaties and customary international law. As one Chinese scholar pointed out: Whether it is peacetime or wartime, whether it is in geospatial or in rights contents, the restrictions on the principle of the freedom of the high seas do have lasted for hundreds of

20 Straddling Fish Stocks Agreement art. 20.

21 R. Churchill \& A. Lowe, The Law of the Sea 209-14 (3d. ed. 1999). 
years. $^{22}$

\section{Major Controversies Arising from Reasonable Restrictions on the Principle of the High Seas Freedoms during BBNJ Negotiations}

During the negotiations on the issues of the BBNJ, several controversies were well noted by negotiating States. First, there are great controversies on the very definition of MPAs, which constitutes a preliminary question for the reasonable restrictions on the freedom of the high seas, and has significant impacts on such restrictions. As to the definition of the MPAs, it is evident that as of today, there is no accurate definition of the high seas MPAs in the international community. Some States suggested to use an adapted version of the CBD Technical Expert Group definition of MPAs or IUCN's definition of MPAs. ${ }^{23}$ Others suggested that the definition of MPAs should be sufficiently broad to encompass specific types of conservation and impact restrictions, depending on the management body in question, such as RFMOs. ${ }^{24}$ In addition, there remain a few States who continue to express reservations about whether a new instrument is really necessary, arguing that strengthening the implementation of existing instruments would be sufficient. ${ }^{25}$ These States include Canada, the US, and Russia. $^{26}$

22 L. Zhang, On the reasonable restriction of state sovereignty on freedom of navigation - from the perspective of the historical evolution of “freedom of the seas” theory [论国家主权对航行自由的合理限制一以“海洋自由论” 的历史演 进为视角], 5 STUDIES IN LAW \& BUSINESS [法商研究] 182 (2015). < available only in Chinese >

23 China, the Group of 77, Jamaica, Japan, Brazil, Costa Rica, New Zealand, Australia and the EU all hold this opinion. For details, see Summary of the First Session of the Preparatory Committee on Marine Biodiversity of Areas beyond National Jurisdiction: 28 March - 8 April 2016, 25:106 IISD Earth Negotiations Bull. (Apr. 18, 2016), available at http://enb.iisd.org/download/pdf/enb25106e.pdf. See also UN Division for Ocean Affairs and the Law of the Sea, Group of 77 (China's Written submission) (Apr. 24, 2017), available at http://www.un.org/depts/los/biodiversity/ prepcom_files/rolling_comp/Group_of_77_and_China.pdf.

24 The US, Chile, Norway all hold this opinion. For detals, see Summary of the First Session of the Preparatory Committee on Marine Biodiversity of Areas beyond National Jurisdiction: 28 March-8 April 2016, 25:106 IISD Earth Negotiations Bull. (Apr. 11, 2016), available at http:/enb.iisd.org/download/pdf/enb25106e.pdf; Summary of the Second Session of the Preparatory Committee on Marine Biodiversity beyond Areas of National Jurisdiction: 26 August - 9 September 2016, 25:118 IISD Earth Negotiations Bull. (Sept. 12, 2016), available at http://enb.iisd.org/ download/pdf/enb25118e.pdf.

25 G. A. Res 69/780, U.N. Doc. A/69/780 (Feb. 13, 2015), available at https://www.undocs.org/A/69/780.

26 E. Morgera, Do We Need a New Treaty to Protect Biodiversity in the Deep Seas?, IISD Policy Brief (Jan. 20, 2015), available at $\mathrm{http} / / \mathrm{sdg}$.iisd.org/commentary/policy-briefs/do-we-need-a-new-treaty-to-protect-biodiversity-in-the-deepseas. 
Second, there are great divergences on the management measures and supervisory measures of the high seas MPAs, which are all directly related to the reasonable restrictions on freedoms of the high seas. The EU called for a consultation mechanism, including a wide range of stakeholders; incorporation of spatial boundaries, conservation objectives, identification of threats and elements of a management plan in the proposals; consideration of a voting mechanism; and respecting rights and obligations under the UNCLOS. ${ }^{27}$ Norway called for discussions on how to link existing management tools to the challenges identified within ABMTs, suggesting that: (1) the ILBI will not have management tools of its own, as these are already enshrined in other bodies' and states' competences; and (2) regional and sectoral bodies be allowed to develop measures to address the pressures and conservation goals identified by the ILBI. ${ }^{28}$ Russia advocated that MPAs should not restrict all activities, or be permanent, recalling coastal state rights to the continental shelf. ${ }^{29}$ Jamaica called for a duty to refrain from activities while proposals are being reviewed, as well as a notification and reporting process, and stricter standards for EIAs in MPAs; it noted, on significant adverse impacts' thresholds, CBD Article 7(c) (identification and monitoring) and the FAO Guidelines on Deep-Sea Fisheries. ${ }^{30}$

Third, some issues that are closely tied to the reasonable restriction measures have caused heated discussions among States in the BBNJ negotiation. First, what is the legal status of marine genetic resources on the high seas MPAs? There are lively discussions on the legal status of marine genetic resources ("MGRs"), whether it should be classified as "the common heritage of mankind" or "res communis." 31 The G-77/China stated that legal gaps on access and benefit-sharing for MGRs sourced from $\mathrm{ABNJ}$ allow some countries to exploit them unilaterally and common heritage is the applicable legal regime. ${ }^{32}$ However, the US stressed that the high seas regime applies to MGRs of $\mathrm{ABNJ}$ and favored promoting research and development benefiting humanity without further administrative and financial burdens. ${ }^{33}$ Legally speaking, if ILBI defines the MGRs as "the common heritage of mankind," it will inevitably place great restrictions on the principle of the high seas freedoms. However, if it is defined as "res communis," only some restrictive measures need to

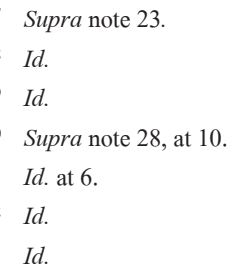


be added to the original basis. Second, what kind of the standards of environmental impact assessments ("EIAs") of the high seas MPAs should be adopted? With the BBNJ negotiations going in depth, there are great disputes on the standards of EIAs among States. The EU, with Cameroon and Algeria, suggested that a state party to the ILBI be responsible for ensuring EIAs are conducted. ${ }^{34}$ While Australia and New Zealand, holding the banner of 'green,' argued that ILBI should set global standards and a scientific committee to guide States in conducting EIAs, they strongly opposed the states-led EIAs. ${ }^{35}$ In addition, some well-known international environmental groups such as IUCN, Greenpeace and WWF supported the establishment of the high seas MPAs and advocated that ILBI should adopt the standards of "radical environmentalism" for EIAs, which is the strictest and the highest environmental standards. ${ }^{36}$ Obviously, different environmental standards mean different management measures. Strict environmental standards are bound to impose strict restrictions on the freedom of the high seas, while loose environmental standards are bound to impose loose restrictions on the freedom of the high seas. Third, three options existed during the BBNJ negotiations on the form of governance: (1) a global model, establishing a global institution to consider and decide on ABMT proposals; (2) a hybrid model, reinforcing regional and sectoral organizations' mandates through regional coordination mechanisms, and providing global guidance and oversight; and (3) a regional and sectoral model, recognizing regional and sectoral bodies' authority for decision-making, monitoring and review of ABMTs, with the ILBI providing general policy guidance to promote cooperation, without global-level oversight. ${ }^{37}$ If a global model is adopted, the global standard and guideline is also needed to be set up for ILBI, which undoubtedly means a deep and wide range of restrictions on the high seas freedoms. However, if a regional and sectoral model is adopted, just a few standards and guidelines are needed to develop, which means a low-level and small-

34 Supra note 28, at 12.

$35 \mathrm{X}$. Hu, International competition around marine biodiversity [围绕海洋生物多样性的国际较量], CHINA OCEAN DAILY (2017). <available only in Chinese >

36 Song Xu, The Impact of the Protection Area of High Seas on the Freedom of High Seas [公海保护区对公海自由 的影响] (unpublished LL.M. thesis, Dalian Maritime University, 2016) (on file with the author) <available only in Chinese $>$

37 Summary of the Third Session of the Preparatory Committee on Marine Biodiversity beyond Areas of National Jurisdiction: 27 March - 7 April 2017, 25:129 IISD Earth Negotiations Bull. 6 (Apr. 10, 2017), available at http:// enb.iisd.org/download/pdf/enb25129e.pdf. The original text reads: "In plenary, Chair Duarte proposed focusing on three options: a global model, establishing a global institution to consider and decide on ABMT proposals; a hybrid model, reinforcing regional and sectoral organizations' mandates through regional coordination mechanisms, and providing global guidance and oversight; and a regional and sectoral model, recognizing regional and sectoral bodies' authority for decision making, monitoring and review of ABMTs, with the ILBI providing general policy guidance to promote cooperation, without global-level oversight." 
scale restriction. The restrictions of the hybrid model stand in between the above two models.

In conclusion, the aforementioned controversial issues have not been solved in two years after four Pre-Committee meetings. As a result, the Preparatory Committee left many gaps or only made principled provisions in the Recommendations of the Preparatory Committee, which can only be discussed in the follow-up meetings. ${ }^{38}$

\section{A Positivist Analysis on Reasonable Restriction to the High Seas Freedoms under the High Seas MPAs}

At present, there are four high seas MPAs in the world, including the Pelagos Sanctuary, the North-East Atlantic Protected Areas, South Orkney Islands Southern Shelf Protected Areas, and Ross Sea Protected Areas.

\section{A. Main Management Measures of the Four High Seas MPAs for the Contracting Parties}

First, the management measures of the aforementioned four high seas MPAs are based on the agreements by the contracting parties. For example, the management measures of the South Orkney Islands southern shelf and Ross Sea are based on the agreements by 36 contracting parties of the Convention on the Conservation of Antarctic Marine Living Resources. ${ }^{39}$ The management measures of the Convention for the Protection of the Marine Environment of the North-East Atlantic are adopted by the agreements of 16 contracting parties. ${ }^{40}$ The management measures under the Pelagos agreement are also signed by the three countries (France, Italy, and the Principality of Monaco). ${ }^{41}$ All the management measures of the four MPAs hereinbefore are legally binding.

Second, the management measures of these four MPAs involve varying degrees of restrictions on fishing, navigation and environmental damage activities, with

38 Supra note 7, at 1-7.

39 Convention on the Conservation of Antarctic Marine Living Resources (Nov. 11, 2014), available at https://documents. ats.aq/keydocs/vol_1/vol1_12_CCAMLR_CCAMLR_e.pdf.

40 Convention for the Protection of the Marine Environment of the North-East Atlantic (Sept. 22, 1992), available at https:/www.ospar.org/site/assets/files/1290/ospar_convention_e_updated_text_in_2007_no_revs.pdf.

41 Presentation of the Pelagos Sanctuary, the official website of Pelagos Sanctuary (Nov. 25, 1999), available at https:// www.sanctuaire-pelagos.org/en/66-anglais/uncategorised/254-presentation-of-the-pelagos-sanctuary. 
different emphasis. On one hand, the management measures of these four MPAs include the monitoring and management of ship navigation, the management of fishery activities, the tracking and assessment of living resources and habitats, and the prevention, control and management of pollution in those regions. On the other hand, the management measures of these four MPAs have different emphasis.

Third, though the management measures of these four MPAs have imposed some restrictions on the contracting parties, exception rules are permitted. For instance, the conservation measures of the South Orkney Islands southern shelf provide that all types of fishing activities shall be prohibited within the defined area, with the exception that scientific fishing research activities agreed by the Commission for monitoring or other purposes on advice from the Scientific Committee and in accordance with Conservation Measure 24-01 are permitted. ${ }^{42}$ And in the case of an emergency relating to safety of life at sea, the prohibitions in this conservation measure shall not apply. ${ }^{43}$ Likely, the conservation measures of the Ross Sea protected area also provide that except as authorized under paragraphs 8, 9 and 21, fishing activities are prohibited within the MPA. ${ }^{44}$ According to Article 7(a) of the Agreement concerning the Creation in the Mediterranean of A Sanctuary for Marine Mammals, any deliberate harassment of a mammal is prohibited. However, non-fatal capture may be permitted in an emergency or in the case of on-site scientific research in accordance with this Agreement. ${ }^{45}$

Fourth, the management measures of the four MPAs comprised several "soft law" clauses on the contracting parties. Legally speaking, the nature of the soft law is oath or initiative, which does not have binding effect. ${ }^{46}$ For instance, the management measures of South Orkney Islands southern shelf protected areas provide that: "For the purpose of monitoring traffic within the protected area, fishing vessels transiting the area are encouraged to inform the Commission for the Conservation of Antarctic Marine Living Resources ("CCAMLR”) Secretariat of their intended transit prior to entering the defined area, providing details of their Flag State, size, IMO number and intended course." ${ }^{47}$ The management measures of the Ross Sea protected area provide:

2 Conservation Measure 91-03 (2009); Protection of the South Orkney Islands Southern Shelf, art. 2.

43 Id. art.6

44 Conservation Measures 91-05 Ross Sea Region Marine Protected Area art.7.

45 Accord Relatif A La Creation En Mediterranee D’un Sanctuaire Pour Les Mammiferes Marins [Agreement on the Establishment of Marine Mammal Protected Areas in the Mediterranean Sea] art. 7(a).

46 Id.

47 Supra note 43, art. 5. 
For the purpose of monitoring traffic within the MPA, in accordance with Conservation Measure 10-04, Flag States must notify the Secretariat prior to entry of their fishing vessels into the MPA. The Flag State may permit or direct that such notifications be provided by the vessel directly to the Secretariat. Vessels conducting scientific research activities on Antarctic marine living resources in or transiting the area are encouraged to inform the Secretariat of their plans for intended passage through the MPA, and vessel details including name, Flag State, size, radio call sign and IMO number. ${ }^{48}$

The Convention for the Protection of the Marine Environment of the North-East Atlantic also provides:

The Contracting Parties shall, in line with the provisions of the Convention, take all possible steps to prevent and eliminate pollution and shall take the necessary measures to protect the maritime area against the adverse effects of human activities so as to safeguard human health and to conserve marine ecosystems and, when practicable, restore marine areas which have been adversely affected. ${ }^{49}$

The following are the management measures of the Pelagos Sanctuary: (1) Contracting parties shall cooperate to regularly assess the status of marine mammal populations, causes of death, threats to habitats, and especially biological activities such as foraging and reproduction; ${ }^{50}$ (2) Contracting parties shall exercise supervision over the Sanctuary and step up prevention of all forms of pollution, pollution from land-based sources or underground resources; ${ }^{51}$ (3) The parties to the agreement adopt a national strategy to gradually reduce the total amount of toxic compounds that enter the Sanctuary and give priority to the substances listed in Annex I of the Protocol to the Barcelona Convention; ${ }^{52}$ and (4) The Contracting Parties shall, through negotiations, regulate and, where appropriate, prohibit activities of boat racing in the Sanctuary. ${ }^{53}$ The terms of 'encourage,' "all possible," 'corporate,' "step up prevention," "gradually reduce" and 'appropriate' in the management measures mentioned above all reflect their nature of "soft law."

52 Id. art. 6(2).

53 Id. art. 9. 


\section{B. Management Measures of the Four High Seas MPAs for Non- contracting Parties}

Among the existing four high seas MPAs, the management measures of Pelagos Sanctuary, the South Orkney Islands southern shelf and Ross Sea have provided the rules for non-contracting parties with the following characteristics:

First, the legal obligations for non-contracting parties are not directly regulated in the management measures. The management measures of the North-East Antarctic MPAs do not refer to the issue of legal obligations for non-contracting parties. In other words, the legal obligations for non-contracting parties have not been introduced in the North-East Antarctic MPAs. Though the other existing three MPAs have the provisions for non-contracting parties, they do not directly impose legal obligations on non-contracting parties.

Second, there are many "soft law" clauses for non-contracting parties in the four high seas MPAs with the aim of promoting the performance of the management measures. For instance, the conservation measures of the South Orkney Islands southern shelf MPAs and Ross Sea MPAs provide that: "The Contracting Parties request non-Contracting Parties to cooperate fully with the Commission with a view to ensuring that the effectiveness of CCAMLR conservation measures is not undermined." $" 54$, the "request non-contracting parties to corporate" is a typical "soft law" clause. Another example is Article 10 of the Convention for the Conservation of Antarctic Marine Living Resources (hereinafter CAMLR Convention). It provides that: "the Commission shall draw the attention of any State which is not a Party to this Convention to any activity undertaken by its nationals or vessels which, in the opinion of the Commission, affects the implementation of the objective of this Convention." And the expression of "draw the attention" is likely a "soft law" clause. It is also noted that the second paragraph of Article 14 of the Agreement concerning the Creation in the Mediterranean of A Sanctuary for Marine Mammals provides that: "Each state party shall have the right to ensure that the provisions of this Agreement apply to ships flying its flag and, in accordance with international law, to ships flying the flag of a third State. ${ }^{, 56}$ It means that if the management measures of the MPAs intend to legally bind the non-contracting parties, they must be in line with international law. Further, only customary international law can be applied to

54 Conservation Measure 118/XX Scheme to Promote Compliance by Non-Contracting Party Vessels with CCAMLR Conservation Measures (Dec. 6, 2018), available at http://archive.ccamlr.org/pu/E/e_pubs/cm/01-02/cm118-XX.pdf.

55 Convention for the Conservation of Antarctic Marine Living Resources art. 10(1).

56 Supra note 45, art. 14(2). 
non-contracting parties because a treaty does not create either obligations or rights for a third State without its consent. However, the problem is that the management measures of the Mediterranean Pegalos Sanctuary have not yet become customary international law and therefore cannot bind non-parties. Hence, the regulations mentioned above are essentially the "soft law" clauses for non-contracting parties to encourage them to perform the management measures.

\section{The Jurisdiction Regime of the Four High Seas MPAs over Illegal Ships}

The existing four high seas MPAs take the flag State jurisdiction as the main jurisdiction and other jurisdictional systems as supplements for the jurisdiction over illegal ships. The specific analyses are as follows.

First, flag state jurisdiction is embodied in the management measures of the existing four high seas MPAs. The jurisdiction on the high seas is different from the national jurisdiction because the high seas are open to all. Therefore, the territorial jurisdiction of States is not applicable to the Areas. In general, the flag State, that is, the State which has granted a ship the right to sail under its flag, has the exclusive right to exercise legislative and enforcement jurisdiction over its ships on high seas. ${ }^{57}$ Public order, therefore, has been pursued through the principle of the nationality of ships and "the jurisdiction of the flag State over the ship" on the high seas. ${ }^{58}$

Second, the conservation measures of the South Orkney Islands southern shelf and Ross Sea provide for the system which authorized the contracting parties to board and further inspect the illegal ships of non-contracting parties. ${ }^{59}$ According to Article 24 of the Convention on the Conservation of Antarctic Marine Living Resources, the Contracting Parties agree that a system of observation and inspection shall be established. To ensure vessels fishing in the Convention Area comply with conservation measures, CCAMLR implements a System of Inspection which introduced specific conditions and procedure for boarding and inspection.

Third, the "long-arm jurisdiction" over non-contracting parties has been introduced in the conservation measures of the South Orkney Islands southern shelf and Ross Sea. For example, according to the Conservation Measures of these two marine protected areas, when a non-Contracting Party vessel referred to in paragraph

57 Supra note 22, at 208.

58 M. Shaw, International Law 443 (7th ed. 2014).

59 CCAMLR, Text of the CCAMLR System of Inspection (Dec.17, 2018), available at https://www.ccamlr.org/en/ system/files/e-pt9_2.pdf. 
4 enters a port of any Contracting Party, it shall be inspected by authorized Contracting Party officials in accordance with Conservation Measure 10-03 and shall not be allowed to land or transship any fish species. Subject to CCAMLR conservation measures it might be holding on board unless the vessel establishes that the fish were caught in compliance with all relevant CCAMLR conservation measures and requirements under this Convention. ${ }^{60}$ In conclusion, the four high seas reserving fundamental management measures for contracting and non-contracting parties are full of their own characteristics.

\section{General Ideas Restricting the High Seas Freedoms by the MPAs}

\section{A. Reality and Graduality}

First, Article 87 of the UNCLOS sets out the principle of the freedom of high seas which means the high seas are open to all States "whether coastal or land-locked."61 Although States are making concessions on the high seas freedoms in order to protect the marine environment, the concessions must have a firmly theoretical basis and realistic foundations. By 2011, discussions under the auspices of the BBNJ Working Group began to focus on what specific changes, if any, would be required to modify the contemporary regime of the law of the sea. The Working Group recommended to the UN General Assembly that:

... a process be initiated ... with a view to ensuring that the legal framework for the conservation and sustainable use of marine biodiversity in ABNJ effectively address those issues by identifying gaps and ways forward, including through the implementation of existing instruments and the possible development of a multilateral agreement under [the UNCLOS]. ${ }^{62}$

In fact, the UNGA Resolution 69/292 stipulates that neither participation in the BBNJ negotiations nor any outcome might affect the legal status of non-parties to the UNCLOS or the legal status of parties to the Convention, including the freedom of the

$60 \quad$ Id. art. 5.

61 Supra note 9.

62 G.A. Res 66/119, U.N. Doc. A/66/119 (annex) art. 1(a) (Dec. 15, 2011), available at https://documents-dds-ny.un.org/ doc/UNDOC/GEN/N11/397/64/PDF/N1139764.pdf?OpenElement. 
high seas under the UNCLOS. ${ }^{63}$ Furthermore, 63 percent countries favored high seas freedoms as principles in the four pre-committee negotiations of the BBNJ. ${ }^{64}$ Also, the Article 4 of Report of the Preparatory Committee established by the UN General Assembly Resolution 69/292 concluded that: "With regard to the relationship to the UNCLOS, the text would state that nothing in the instrument shall prejudice the rights, jurisdiction and duties of States under the UNCLOS." ${ }^{65}$ As one scholar points out, what distinguishes implementing agreements from other agreements in terms of their normative status and effects is their close relationship to the UNCLOS. ${ }^{66}$ As to the BBNJ, under the general principles of the UNCLOS, such as the freedom of the high seas and responsibility to protect and preserve the marine environment, further clarification and development are required to suit present needs and circumstances. Thus, the principle of the high seas freedoms under the UNCLOS is not only the basis of the international law of the sea, but also that of the BBNJ negotiations.

Second, the principle of State sovereignty and the freedom of the high seas are playing a game under the premise of coexistence, which is a long-time process, while neither of them can completely override the other in this regard. On one hand, protecting marine environment is an irresistible trend. With the marine environment continuing to deteriorate and marine biodiversity being threatened, more and more countries, international organizations and individuals pay great attention to the issue of marine environmental protection. Accordingly, traditional freedom of the sea has got more and more restrictions. On the other hand, any step forward to restrict the freedom of the high seas is very difficult in the contemporary international community constituted by sovereign states. The international community should balance the interests of all parties cautiously, continuously improve the global governance mechanism and set limitations on freedom of the high seas step by step. Consequently, the restrictions on the high seas freedoms by sovereign States would not advance quickly, but rather in a slow process. The coastal and the flag states reached a certain kind of balance of power in different historical periods, which constructed the system of high seas freedoms in that period for quite a long time.

Third, in practice, unilateral management measures on the high seas have received fierce oppositions from other States. For instance, in order to conserve and recover the ecosystem as well as the fishery resources, Canada adopted Fishery Act in 1976 to establish the exclusive fishing areas and to implement the stricter regulations

\footnotetext{
63 Supra note 7 , at 2.

64 Resource from four pre-committee report, supra note 9.

65 Supra note 7, at 8-9.

66 Supra note 4 , at 4.
} 
on fishing activities in the areas. Since the two corners, which covered 10 percent of the total areas of the Grand Banks, are located in areas beyond Canada's 200 nautical miles exclusive economic zone, they were not within the national jurisdiction of Canada. Cross border fish species in Canada's exclusive fishing zones or high seas were threatened with extinction by overfishing, in which foreign fishery vessels have engaged for a long time. Consequently, Canada amended the Coastal Fisheries Protection Act on May 12, 1994, authorizing Canadian law enforcement vessels to investigate and arrest foreign fishery vessels engaged in high seas fishing near the Grand Banks. ${ }^{67}$ Meanwhile, Canada claimed jurisdiction over these fishing vessels pursuant to the Act. From the legal viewpoint, the Amendment of Coastal Fisheries Protection Act violated customary international law that ships are not subject to nonflag states' jurisdiction on the high seas as recognized by most States. As a result, it caused diplomatic protests and oppositions from other countries. Moreover, the European Commission handed Canada an oral diplomatic note, stating that the Amendment of the Act was not only inconsistent with international law, but also the international community's efforts to improve the management of fishery resources, especially high seas fisheries resources, particularly the legal framework established by the Food and Agriculture Organization and the United Nations Conference on Straddling Fish Stocks. The US in a diplomatic note to Canada stressed that: "the unilateral actions taken by coastal states undermined the balance of benefit under the UNCLOS. ... No entitlement, in pursuant to the UNCLOS, granted coastal states to visit, verify or seize a ship on the high seas without permission from flag states." ${ }^{\prime 68}$

In conclusion, concerning the reasonable restrictions on high seas freedoms in MPAs, only by taking into considerations of all economic and political interests of related countries, we can maintain the integrity of legal logic and guarantee the compliance of the treaty. Therefore, it may take many years to achieve this goal.

\section{B. Positive Law}

First, the principle of the high seas freedoms, embodied in the modern international law of the sea based on positive law, can be restricted on account of practical needs under the premise of agreements by all countries. Natural law theory, sustained by Grotius, is no longer the foundation of the modern international law of the sea; it

67 Coastal Fisheries Protection Act Amendment (May. 12, 1994), §7, available at https://www.un.org/Depts/los/ LEGISLATIONANDTREATIES/PDFFILES/CAN_1994_Amendment.pdf.

68 W. Dunlap, Canada Asserts Jurisdiction over High Seas Fisheries, IBRU Boundary \& SeCurity Bull. 65 (July 1994), available at $\mathrm{https}: / /$ www.dur.ac.uk/ibru/publications/download/?id=42. 
has been replaced by the positive law theory that was advocated by Bynkershoek and developed for many decades. ${ }^{69}$ Hence, pursuant to the positive law, the high seas freedoms can be regarded neither as sacred and inviolable, nor as the moral advantages for supporters. Rather, the judgment of right and wrong shall be based on the actual situations.

Second, the high seas MPAs, established by States through negotiations, are based on the common interests of these States. Since States are still the main subjects of international law, the conservation measures of the high seas MPAs should be implemented mainly by the contracting States in goodwill. Moreover, the implementation of the high seas MPAs is in essence affected by various powers in the international community. One of the most important reasons why the establishment of the high seas MPAs can be put on the UN agenda as well as the negotiating tables of countries is that the States share common interests especially in environment. In particular, the practical experience of the four high seas MPAs showed that the management measures of the high seas MPAs to restrict the high seas freedoms, cannot legally bind non-contracting parties, but only bind contracting parties with their agreements.

Third, there are great disputes among States on what kind of measures and approaches they might take to restrict the high seas freedoms during the BBNJ negotiations. Accordingly, it becomes the key issue regarding how to balance the interests of all countries in the process of BBNJ negotiations in the future, to which all countries pay attention. To achieve the aim of a "comprehensive global regime" on the conservation and sustainable use of marine biodiversity of ABNJ, any new instrument should secure widespread acceptance. It is also significant that the UN will serve the forum for concluding the new instrument, following consensus decision-making techniques. ${ }^{70}$ In other word, when only all the parties reach consensus can the high seas freedom be reasonably restricted.

\section{Legal Objectivity}

Now that we support the reasonable restrictions on the high seas freedoms, how to define the term 'reasonable' is the next crucial step. It is submitted that the term 'reasonable' involves 'law' and 'reason' at the same time, both of which are in a

69 C. van Bynkershoek, R. van Deman Magoffin, J. Brown Scott, De Dominio Maris Dissertatio [On Maritime SovereIgnty] 44 (A Photographic Reproduction of the Second Edition of 1744 with an English Translation by Ralph Van Deman Magoffin and an Introduction by James Brown Scott, Oxford University Press, 1923).

70 Supra note 4, at 4. 
relationship of dialectical unity.

First, the restrictions on the high seas freedoms should be in accordance with law. The term 'law' refers to the international rules currently in effect, including international treaties, customary international law and the general principles of law. For example, all the related parties, who have established the four high seas MPAs by consensus, formulated the international treaties to exert reasonable restrictions on navigation, fishing, scientific research and dumping on the high seas.

Second, the restrictions on the high seas freedoms should be in accordance with reason. 'Reason' may be defined as human conscience and rationality. A basic assumption of individual person is that everyone is rational, just as the Universal Declaration on Human Rights ("UDHR") says: "All human beings are born free and equal in dignity and rights. They are endowed with reason and conscience and should act towards one another in a spirit of brotherhood." ${ }^{, 71}$ For example, all the contracting parties take measures to monitor and manage the traffic of ships in the four high seas MPAs by treaties, based on the consideration to protect the marine environment. Specifically, for the purpose of monitoring traffic within the protected area, the conservation measures of the South Orkney Islands southern shelf lays down that fishing vessels transiting the area are encouraged to inform the CCAMLR Secretariat of their intended transit prior to entering the defined area, providing details of their Flag State, size, IMO number and intended course. ${ }^{72}$ Taking another example, the four high seas MPAs all take some restriction measures on fishing, based on the consideration to conserve fishery resources, but the Ross Sea protected areas established the quota system to limit the quality of catching. ${ }^{73}$ It can be concluded that the treaties establishing the four high seas MPAs provide a series of reasonable management measures that have been agreed by all contracting parties for the high seas environmental protection.

Third, the restrictions on the high seas freedoms shall reflect the unity of law and reason. A feasible way is to adhere to the principle of sustainable development and precautionary approaches in international environmental law. Sustainable development meets the present needs without compromising the ability of future generations to meet their own needs. ${ }^{74}$ According to the principle of sustainable development, the international community can also take some restriction measures on the high seas freedoms for marine environment protection. In other word, these

1 UDHR art. 1.

2 Supra note 43 , art. 5.

73 Supra note 45 , art. 8.

74 P. Sands, Principles of International EnVIronmental Law 198 (4th. ed. 1995). 
measures should be in accordance with both law and reason. For example, in Bering Sea Arbitration of 1893, while the tribunal ultimately did not rule in favor of the US on the basis of the principle of high seas freedoms, it has set up certain protective measures for the seals on the high seas on account of the principle of sustainable development, including the closed season, hunting methods and hunting tools. ${ }^{75}$ For another example, in the preambular elements of recommendations, the Preparatory Committee noted that recognition of the need for the comprehensive global regime to better address the conservation and sustainable use of marine biological diversity of ABNJ. ${ }^{76}$ In addition, the precautionary approach means that: "In order to protect the environment, the precautionary approach shall be widely applied by States according to their capabilities. Where there are threats of serious or irreversible damage, lack of full scientific certainty shall be not used as a reason for postponing cost-effective measures to prevent environmental degradation." ${ }^{, 77}$ The 'approach' is generally considered as a softening of the 'principle,' according to the precautionary approach. The restriction measures on high seas freedoms can be taken to protect the environment of the high seas and living resources, but these restriction measures should be in accordance with reason and law. For example, the Convention for the Protection of the Marine Environment of the North-East Atlantic provides the precautionary approach as the fundamental principle of North-East Atlantic Marine Protected Areas. ${ }^{78}$ For another example, the general principles and approaches of recommendations are set out for guiding the conservation and sustainable use of marine biological diversity of areas beyond national jurisdiction, including precautionary approaches and many other general principles. ${ }^{79}$

Last, based on the principle of unification of law and reason, some new measures to protect the marine environment in $\mathrm{ABNJ}$ can be considered in the BBNJ document. As recognized by the General Assembly in its 2014 Resolution on the Oceans and the Law of the Sea and other international bodies, rising greenhouse gas emissions may be one of the gravest threats to marine biodiversity both in and outside of ABNJ in the coming years. ${ }^{80}$ The International Law Association prescribes that: "States and competent international organizations shall apply, interpret, implement and enforce their rights and obligations under the Law of the Sea in such a manner so

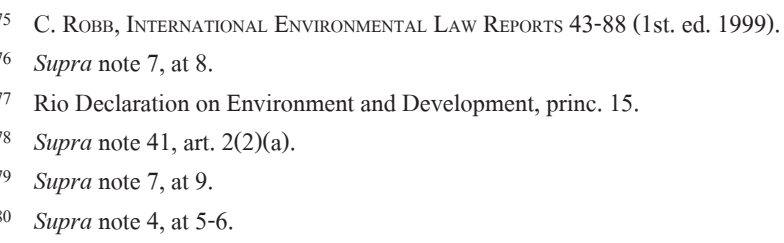


as to effectively address climate change and its adverse effects. ${ }^{" 81} \mathrm{~A}$ new treaty on the conservation and sustainable use of marine biodiversity in ABNJ can make a significant contribution to satisfy this principle by both incorporating mechanisms for increasing ecosystem resilience, for example, through the creation of marine protected areas, and requiring that environmental impact assessments be conducted for new and emerging ocean activities relating to climate change.

\section{Details for the Reasonable Restrictions on the High Seas Freedoms}

\section{A. The Management Measures of the High Seas MPAs without the Obligations on Non-Contracting Parties}

For the purpose of protecting the marine environment, the high seas MPAs can set up some management measures, which can only bind the contracting parties, rather than non-contracting parties. First, the high seas MPAs cannot impose the obligations on non-contracting parties under the pacta tertiis nec nocent nec prosunt. Article 34 of the Vienna Convention on the Law of Treaties provides the principle of pacta tertiis nec nocent nec prosunt which that: "A treaty does not create either obligations or rights for a third State without its consent." Hence, the management measures of the high seas MPAs can only bind the contracting parties, instead of the non-contracting parties.

Second, the UNCLOS could not be deemed as the legal basis to set obligations for the non-contracting parties. According to Article 192 of the UNCLOS, states are obliged to protect and preserve the marine environment, and by now, there are 168 contracting parties of the UNCLOS. ${ }^{82}$ Many provisions of the UNCLOS have developed into the customary international law. ${ }^{83}$ Thus, some authors hold that Article 192 of the UNCLOS is customary international law, with general legal binding forces on all States. ${ }^{84}$ However, Article 192 of the UNCLOS is not only relatively

81 Draft of Legal Principles relating to Climate Change art.10(c), available at http://climatestrategies.org/wp-content/ uploads/2014/10/Schwarte-C.-Session-3.pdf.

82 Until March 27, 2018, there were 168 contracting parties of the United Nations Convention on the law of the sea. See UN Treaty Series, United Nations Convention on the Law of the Sea, available at https://treaties.un.org/pages/ ViewDetailsIII.aspx?src=TREATY\&mtdsg_no=XXI-6\&chapter=21\&Temp=mtdsg3\&clang=_en.

83 Supra note 22, at 24.

84 T. Scovazzi, Marine protected areas on the high seas: some legal and policy considerations, 19 InT'L J. MARINE \& COASTAL L. 1-17 (2004). 
vague and general, but also lacks of details on obligations, which cannot create the concrete contents of rights and obligations for the States. Furthermore, the ambiguity of the contents of the obligations and the standards of the breach of Article 192 results in the impossibility of enforcement.

Finally, in practice, the effect of the four high seas MPAs is not obvious, let alone the formation of new customary international law. State practice and opinio juris are the two essential elements of customary international law, and the state practice should meet the requirements of time, numbers of countries and consistency at the same time. ${ }^{85}$ In other word, such State practice must be common, consistent and concordant. However, contradiction in the States practice or inconsistent conduct, particularly emanating from these very States which are said to be following or establishing the custom, would prevent the emergence of a rule of customary law. ${ }^{86}$ As the duration periods of the high seas MPAs would range from 5 to 15 years, which is too short, the effect is not obvious yet. As to the numbers, at present, there are only four high seas MPAs in the world, of which the Mediterranean Pegalos Sanctuary is not a full sense of high seas MPAs. The total area of four high seas MPAs is less than one hundredth of high seas in the world. Moreover, there are 36 contracting parties of the South Orkney Islands southern shelf and Ross Sea region marine protected area, 16 contracting parties of the North-East Antarctic marine protected areas, and 3 contracting parties of the Mediterranean Pegalos Sanctuary, all of which cannot meet the quantitative requirements of the vast majority of States in the world. In addition, the practice of four high seas MPAs cannot satisfy the requirement of consistency due to the great differences among them. Therefore, the practice of the four high seas MPAs has not yet formed a new customary international law, nor can it impose obligations on non-contracting States. Only when the management measures of high seas MPAs have formed new customary international law can obligations be imposed on non-contracting States.

\section{B. The Management Measures of High Seas MPAs under the Right to Visit and the Long-arm Jurisdiction}

First, the management measures of the high seas MPAs should strictly regulate the right to visit. Considering the nature of the right to visit, it should not be regarded

85 UN, Identification of Customary International Law (Nov. 22, 2018), at 124, available at http://legal.un.org/ docs/?path=.//ilc/reports/2018/english/chp5.pdf\&lang=EFSRAC.

86 Fisheries Jurisdiction (U.K. v. Ice.), Joint Separate Opinion of Judges Forster, Bengzon, Jiménez de Aréchaga, Nagendra Singh and Ruda, 1973 I.C.J. Rep. 51 (July 25), available at https://www.icj-cij.org/en/case/55/judgments. 
as a kind of universal jurisdiction stemming from the illegal action incurred on the high seas. This has not yet reach the extent of undermining international peace and order seriously. The right to visit on the high seas MPAs, which is applied to the non-flag states on their breaches of the management measures on navigation, flying, fishing and scientific research in the protected areas, is usually for the purpose of environmental protection. Thus, the scopes of the right to visit on the high seas MPAs are broader than those provided in the UNCLOS. In comparison, the right to visit under the UNCLOS, which authorized all states to have jurisdiction over international crimes on the high seas, ${ }^{87}$ is mainly based on the universal jurisdiction to maintain law and order of the high seas. As to the enforcement body of the right to visit on the high seas MPAs, it includes the ships or officers of the contracting parties, rather than the warship, military aircraft and any other duly authorized ships or aircraft clearly marked and identifiable as being on government service under the UNCLOS. ${ }^{8}$ Hence, broadening the scopes of enforcement body on the high seas MPAs relatively is violating the objective and purpose of the right to visit on the high seas MPAs. In order to further regulate the right to visit, the enforcement body and procedures of the right to visit should be strictly regulated. As to the enforcement body, Article 110(1) and (5) of the UNCLOS could be deemed as a model. As regard the enforcement procedures, the conservation measures of the South Orkney Islands southern shelf and Ross Sea could be referred to. ${ }^{89}$

Second, the management measures of the high seas MPAs should strictly regulate the Long-arm jurisdiction. Since it is impossible for the management measures of the high seas MPAs to have legal binding effects on non-contracting parties under international law, the jurisdiction of contracting parties over the illegal actions of noncontracting parties, especially breaching the management measures of the high seas MPAs, is not based on adequate law. In this regard, for example, a Long-arm of the $\mathrm{US}^{90}$ has been often criticized by some countries in practice. ${ }^{91}$ If the ILBI allows the contracting parties to apply the Long-arm Jurisdiction to all the illegal actions of noncontracting parties, it would not only infringe the credibility and authority of the high seas MPAs, but also be likely opposed by the non-contracting parties.

Third, considering the practice of the existing high seas MPAs, the conservation

87 UNCLOS art. 110.

88 Id. art. 110(1) \& (5).

89 Supra note 60, arts. 3, 6, $7 \& 11$.

90 Philadelphia and Reading Railway Co. v. McKibbin, 243 U.S. 264 (1917); St. Louis Southwestern Railway Co. of Texas v. Alexander 227 U.S. 218 (1913). For details, see C. Rhodes, Clarifying General Jurisdiction, 34 SETON HALL. L. Rev. 807-10 (2004).

91 R. Brand, Due Process, Jurisdiction and A Hague Judgments Convention 60 U. PItr. L. Rev. 691 \& 695 (1999). 
measures of the South Orkney Islands southern shelf and Ross Sea have set Longarm Jurisdiction on illegal, unreported and unregulated ("IUU") fishing. If there is evidence that the vessel has fished in contravention of CCAMLR conservation measures, in particular when the fishing vessel is included in a list of IUU vessels adopted by CCAMLR in accordance with Conservation Measure 10-06 or 10-07, the Contracting Party shall prohibit the vessel from landing or trans-shipping the catch, or take other monitoring, control, surveillance or enforcement action of equivalent or greater severity in accordance with international law. The Contracting Party shall inform the Flag State of the vessel of its inspection findings and shall cooperate with the Flag State in taking such appropriate action as is required to investigate the alleged infringement and, if necessary, apply appropriate sanctions following national legislation. ${ }^{92}$ On June 5, 2016, Agreement on Port State Measures to Prevent Deter and Eliminate Illegal, Unreported and Unregulated Fishing came into force. ${ }^{93}$ According to the Agreement, vessels will be required to prove that they are licensed to fish by the flag State and have the necessary permissions from the countries in the waters they operate. If not, or if inspections turn up the evidence of IUU fishing activity, vessels will be denied any further use of ports and reported as violators. ${ }^{94}$ Arguably, many countries has the consensus to fight against IUU fishing. The author believes that the high seas MPAs can provide for Long-arm Jurisdiction over noncontracting States in IUU fishing matters, but strict conditions and procedures are necessary.

To sum up, the management measures of the high seas MPAs should strictly regulate the right to visit, as well as the Long-arm Jurisdiction.

\section{Soft Law and Exception Rules}

First, there are sharp disputes in the international community over the management measures and their nature. If some "soft law" clauses are adopted, they can undoubtedly play a critical role in promoting the high seas MPAs to build consensus and guide action. As mentioned above, there are sharp disputes among States on the very definition, the management and supervisory measures during the process of BBNJ negotiations. While the "soft law" clauses can maintain flexibility, it has two

92 CCAMLR, Conservation Measure 10-03 (2015); Port Inspections of Fishing Vessels Carrying Antarctic Marine Living Resources (Dec. 5, 2018), available at https://www.ccamlr.org/en/measure-10-03-2015.

93 See UN agency announces world's first illegal fishing treaty now in force, UN NEws, June 5, 2016, available at https:// news.un.org/en/story/2016/06/531252-un-agency-announces-worlds-first-illegal-fishing-treaty-now-force.

94 Agreement on Port State Measures to Prevent, Deter and Eliminate Illegal, Unreported and Unregulated Fishing, arts.13 \&18, available at $\mathrm{http}: / /$ www.fao.org/fileadmin/user_upload/legal/docs/037t-e.pdf. 
aspects of meanings: on one hand, the international community takes joint action in order to "seek common ground," but difference remains. Hence, States need to keep flexibility to "reserve difference." On the other hand, since joint actions have the possibility to fail or make a great adjustment, States also need policy flexibility to "try and error." Obviously, "soft law" clauses can not only "reserve difference," but also "try and error." Thus, "soft law" clauses can satisfy the needs of the international community for flexibility.

Second, from the practical experience of the four high seas MPAs, many "soft law" clauses are adopted to achieve the purpose of building consensus and boosting cooperation. The above practice is worthy of reference and consideration by all States in the negotiation process of ILBI.

Third, the "soft law" clauses of the high seas MPAs can be applicable mainly to the following: (1) In order to achieve the overall goal of marine protected areas to protect the marine environment, the soft law clause shall be applied to keep the necessary space and flexibility; (2) Management measures involving fishing, navigation, overflight, scientific research, etc. in the protected areas that are highly divergent by the Parties are suitable for adopting "soft law provisions" instead of rigid standards; (3) Regarding the management measures of non-parties, it is appropriate to adopt the "soft law" clause to achieve the purpose of urging non-parties to comply with the management measures of the high seas MPAs.

Finally, from the practical experience of the four high seas MPAs, exception rules of the management measures should be adopted such as exceptions to scientific research activities, those involving endangering the safety of life at sea, and those authorized.

\section{Conclusion}

In this research, the author has reviewed the four recognized high seas MPAs with special references to reasonable restrictions on freedom of high seas. This paper has finally revealed some critical features of the practice. Accordingly, the international community should gradually carry forward future restrictions on the freedom of the high seas. Furthermore, the international community should not set legal obligations for non-parties. As a consequence, it should strictly regulate the right of visit and Long-arm jurisdiction, and apply soft law provisions. 